\title{
Membangun Siswa Tangguh Bencana di Cimanggu Pandeglang
}

\author{
Retno Dyah Kusumastuti ${ }^{1 *}$, Andi Kurniawan ${ }^{2}$ \\ ${ }^{1,2}$ Fakultas Ilmu Sosial dan Ilmu Politik Universitas Pembangunan Nasional Veteran \\ Author E-mail: retnodyah@upnvj.ac.id
}

\begin{abstract}
A B S T R A K
Anak-anak merupakan salah satu kelompok masyarakat yang rentan terhadap bencana. Menurut beberapa penelitian, anak-anak dan perempuan seringkali menjadi korban terbanyak dalam peristiwa bencana. Bencana tsunami Selat Sunda yang terjadi akhir tahun 2018 lalu merupakan pelajaran penting bahwa kesiapsiagaan masyarakat perlu ditingkatkan khususnya kepada anak-anak di sekitar wilayah berpotensi terkena dampak tsunami, termasuk di Cimanggu salah satu kecamatan terdekat dengan pantai Sumur Pandeglang. Kegiatan literasi yang dilakukan dalam bentuk penayangan video kesiapsiagaan bencana yang dibuat oleh BNPB dan umpan balik dalam bentuk kuiz. Selain itu, alat peraga informasi kesiapsiagaan bencana juga dibuat dalam bentuk standing banner yang mudah dan menarik untuk dibaca.
\end{abstract}

Kata Kunci: Tsunami Pandeglang, literasi bencana, kesiapsiagaan Anak-anak.

\section{A B S T R A C T}

Children are a group of people who are vulnerable to disasters. According to several studies, children and women are often become victims in disaster events. The Sunda Strait tsunami that occurred at the end of 2018 provides an important lesson that community preparedness needs to be improved, especially for children around the area potentially affected by the tsunami, including in Cimanggu, one of the closest sub-districts to the Sumur Pandeglang beach. Literacy activities are carried out in the form of showing disaster preparedness videos made by BNPB and quiz feedback. In addition, the disaster preparedness information props were also made in the form of standing banners that were easy and interesting to read.

Keywords: Pandeglang Tsunami, Disaster Literation, Hildren Readiness.

Copyright (C) 2020 Authors. This is an open access article distributed under the Creative Commons Attribution License, which permits unrestricted use, distribution, and reproduction in any medium, provided the original work is properly cited.

\section{PENDAHULUAN}

Indonesia telah dilanda beberapa kali bencana alam dari gempa bumi, letusan gunung berapi hingga Tsunami. Tidak hanya kerusakan infrastruktur dan hunian penduduk, korban jiwa meninggal akibat bencana alam di Indonesia diperkirakan telah mencapai ribuan. Letak geografis Indonesia yang berada di Cincin Api
Pasifik (Pacific Ring of Fire) menjadikan Indonesia sebagai salah satu negara dengan potensi bencana alam yang cukup signifikan. Setidaknya terdapat enam bencana terparah sepanjang 2018, diantaranya adalah gempa bumi 6.1 SR yang terjadi pada 23 Januari 2018 di barat daya Kabupaten Lebak, Banten yang menyebabkan 
kerusakan rumah sebanyak 2.760 unit. Satu bulan kemudian, bencana tanah longsor terjadi di Brebes pada Februari 2018 dengan perkiraan kerugian mencapai Rp 7 milyar. Tidak hanya itu, gempa kembali terjadi di Lombok dengan kekuatan 7.0 SR pada bulan Agustus 2018 serta di Palu dan Donggala pada bulan September 2018 dengan kekuatan 7.4 SR yang diikuti dengan gelombang Tsunami. Indonesia sendiri dikelilingi oleh 4 lempeng tektonik, yaitu Australasia, Pasifik, Eurasia, dan Filipina. Selain itu, di Indonesia juga terdapat 129 gunung berapi aktif. Hal ini menyebabkan Indonesia rentan terhadap sejumlah bencana, seperti erupsi gunung berapi, gempa bumi, dan tsunami.

Iklim di Indonesia sendiri dipengaruhi oleh lokasi geografisnya yang diapit Samudera Hindia dan Samudera Pasifik. Terdapat 3 pola iklim di Indonesia, yaitu khatulistiwa, monsunal, dan sistem iklim lokal. Hal ini menyebabkan adanya perbedaan curah hujan yang cukup signifikan di wilayah-wilayah yang berbeda. Di sisi lain, seiring dengan terjadinya pemanasan global, hal tersebut menimbulkan sejumlah dampak, seperti perubahan iklim, kenaikan suhu, dan kenaikan permukaan air laut. Adanya perbedaan curah hujan sekaligus dampak dari pemanasan global, mengakibatkan Indonesia rentan terhadap berbagai bencana hidrometeorologi, seperti kekeringan, banjir, banjir bandang, cuaca ekstrim, kebakaran hutan dan lahan (Karhutla), serta abrasi.

Kejadian terbaru adalah Tsunami Selat Sunda yang menerjang Banten dan Lampung pada 22 Desember 2018. Bencana tersebut menelan korban jiwa sebanyak 426 jiwa, dimana korban jiwa terbanyak berada di Kabupaten Pandeglang, yaitu sebanyak 288 jiwa. Bencana Tsunami Selat Sunda ini selain menyebabkan banyak korban termasuk para wisatawan yang sedang menikmati liburan di Pantai Tanjung Lesung, akan tetapi juga menimbulkan kontroversi di kalangan akademisi dan para pemangku kebijakan yang selama ini mempercayai bahwa Tsunami akan diawali dengan gempa bumi. Faktanya, Tsunami Selat Sunda yang terjadi akhir tahun kemarin tidak didahului dengan gempa bumi, hanya tanda-tanda air pasang yang diperkirakan sebagai sesuatu hal yang biasa.

Dalam sejumlah literatur Pandeglang dikategorikan sebagai salah satu wilayah rentan bencana alam mengingat letak geografisnya yang memiliki garis pantai sepanjang $307 \mathrm{~km}$ dan berdekatan dengan Gunung Krakatau. Salah satunya adalah potensi tanah longsor di beberapa wilayah di kabupatean Pandeglang meliputi Kec. Cigeulis, Panimbang dan Mandalawangi. Potensi bencana alam lainnya adalah gempa bumi dimana sekitar $45 \%$ daerah di Banten rentan terhadap bencana gempa bumi. Daerah di Banten yang rawan mengalami gempa bumi adalah daerah di sisi selatan dan barat. Selain adanya potensi erupsi dari Gunungapi Anak Krakatau, Banten juga perlu mengantisipasi potensi erupsi Gunungapi Pulosari di Pandeglang. Gunungapi ini meskipun belum meletus, namun masih aktif. Hal ini dibuktikan dengan adanya sumber air panas di sekitar gunung tersebut. (Soleman, Nurcahyani, \& Munajati, 2012).

Tidak hanya itu, salah satu kawasan yang juga dianggap rentan terhadap bencana khususnya tsunami dan aktivitas Anak Gunung Krakatau adalah Kecamatan Sumur dan Cimanggu, Pandeglang. Menurut siaran pers WWF Indonesia, dua kecamatan tersebut termasuk dalam wilayah penyangga Taman Nasional Ujung Kulon (TNUK) yang rentan terhadap bencana seperti erupsi gunung meletus dan tsunami yang disebabkan oleh aktivitas Anak Gunung Krakatau. Diperlukan perhatian khusus terhadap masyarakat yang bermukim di kedua wilayah tersebut dalam rangka kesiapsiagaan dan penanggulangan bencana (WWF Indonesia, 2019). Hal ini sejalan dengan data resmi dari Badan Nasional Penanggulangan Bencana (BNPB) bahwa korban jiwa akibat dari Tsunami Selat Sunda sebagian besar berada di wilayah Panimbang, Sumur dan lokasi wisata Tanjung Lesung.

Berdasarkan survei pasca kejadian gempa besar Hanshin Awaji di Jepang, 35\% korban yang selamat menyelamatkan dirinya sendiri, 
$31,9 \%$ diselamatkan oleh keluarganya, 28,1\% diselamatkan oleh teman atau tetangga, 2,6\% diselamatkan oleh orang yang melewati wilayah tersebut, $1,7 \%$ diselamatkan oleh tim SAR, dan $0,9 \%$ diselamatkan oleh pihak lain. Berdasarkan temuan survei tersebut, dapat disimpulkan bahwa hal terpenting adalah penguasaan pengetahuan ketahanan bencana yang ada dalam diri sendiri. Setelah itu, barulah diikuti oleh bantuan dari pihak lain (keluarga, teman, tetangga, dan tim SAR). Oleh karena itu, pelatihan kebencanaan (dengan tema Latihan Kesiapsiagaan Bencana Siap, Untuk Selamat!) memiliki peran penting dalam meningkatkan ketahanan terhadap bencana, serta meningkatkan kemampuan untuk menyelamatkan diri. Pelatihan tersebut penting agar masyarakat memahami mengenai bencana, serta berkontribusi untuk melindungi orangorang di sekitarnya dari ancaman bencana. Selain itu, dengan adanya keterikatan sosial, rasa saling mempercayai, dan gotong royong, hal-hal tersebut merupakan modal sosial yang penting untuk mengantisipasi serta memitigasi bencana, dan membantu pemulihan dampak dari bencana.

Sebagai langkah dalam menciptakan ketahanan sosial sekaligus budaya sadar bencana, terdapat 3 bagian dari ketangguhan bencana yang perlu ditumbuhkan (Bene et al., 2012), yaitu kapasitas untuk memitigasi bencana (absorptive), kapabilitas untuk beradaptasi dan menyesuaikan terhadap bencana (adaptive), dan kemampuan untuk berubah (transformative) yang menghasilkan usaha-usaha untuk berubah. Salah satu hal yang perlu dilakukan dalam menciptakan ketahanan terhadap bencana adalah melalui latihan kesiapsiagaan. Terdapat sejumlah jenis latihan kesiapsiagaan, yaitu: (1) Pengaktifan Sirene Peringatan Dini, (2) Latihan Evakuasi Diri di permukiman, sekolah/madrasah, gedung bertingkat, dan rumah sakit, dan (3) Uji Terap Tempat Pengungsian Temporer/Permanen di seluruh Indonesia. Latihan kesiapsiagaan secara khusus juga dilakukan dengan mengikutsertakan kelompok tertentu, contohnya lansia, anak-anak, penyandang disabilitas, orang berkebutuhan khusus, dan tunawisma.
Dari banyak peristiwa bencana alam tersebut seharusnya kita menyadari bahwa potensi bencana alam dapat terjadi kapanpun dan dimanapun. Namun disayangkan bahwa kesadaran ini belum semuanya dimiliki oleh masyarakat khususnya mereka yang menetap di wilayah-wilayah dengan potensi bencana seperti masyarakat pesisir pantai dan penduduk di sekitar gunung berapi. Lebih dari itu, aktivitas terkait dengan kebencanaan sebagian besar masih terkonsentrasi pada kegiatan setelah bencana dalam bentuk respon kedaruraratan dan pemulihan (emergency response and recovery). Di sisi lain, kegiatan sebelum bencana yang mengedepankan mitigasi bencana/kesiapaan bencana (disaster mitigation / disaster preparedness) masih relatif terbatas, meski dampak bencana pada dasarnya telah menyebabkan kerusakan parah dan korban jiwa di hampir semua wilayah di Indonesia yang pernah dilanda oleh bencana alam (Prihatmaji, 2013).

Untuk itu, perguruan tinggi dapat menjalankan perannya sebagai institusi pendidikan yang hadir dalam memberikan literasi dan pemberdayaan masyarakat agar senantiasa siap dan siaga dalam penanggulangan bencana alam di wilayah tempat tinggal mereka. Salah satunya adalah di wilayah Cimanggu, Kabupaten Pandeglang, sebagai salah satu lokasi penyangga Taman Nasional Ujung Kulon yang rentan terhadap bencana erupsi Anak Gunung Krakatau dan gelombang tsunami sebagaimana yang telah terjadi pada akhir 2018 yang lalu.

\section{METODE KEGIATAN}

Kegiatan sebelum bencana masih membutuhkan perhatian seluruh pihak, termasuk perguruan tinggi yang memiliki tanggung jawab sosial untuk menjawab permasalahan-permasalahan yang dihadapi oleh masyarakat. Secara umum, kegiatan pre-disaster management meliputi kegiatan pencegahan, yaitu aktivitas yang lebih diarahkan pada usaha untuk mencipkan berbagai produk perundang-undangan yang ditujukan untuk menurunkan risiko bencana, seperti peraturan mengenai IMB, rencana tata guna lahan/tanah, 
serta rencana penyusunan peta rawan bencana. Kegiatan kedua adalah aktivitas mitigasi dalam rangka menurunkan efek yang dihasilkan oleh bencana, seperti pembangunan tanggul, rehabilitasi saluran, serta normalisasi saluran. Kegiatan ketiga adalah kegiatan kesiapsiagaan, seperti kegiatan pelatihan, pendidikan, dan penyuluhan mengenai kebencanaan, baik kepada masyarakat, petugas di lapangan, maupun aparatur pemerintah (Prihatmaji, 2013).

Sejumlah kegiatan yang dapat dilakukan pra bencana antara lain pelatihan peningkatan kesadaran bencana (disaster awareness), pelatihan penanggulangan bencana (disaster drill), pengadaan teknologi tahan bencana, pembangunan sistem sosial yang tanggap terhadap bencana, serta perumusan kebijakankebijakan antisipasi bencana (disaster management policy). Dalam kegiatan ini, tim Abdimas UPNVJ menyelenggarakan peningkatan kesadaran masyarakat (disaster awareness) yang melibatkan siswa sekolah di Kecamatan Cimanggu, Pandeglang. Siswa sekolah dipilih sebagai sasaran kegiatan ini, dikarenakan anak-anak adalah salah satu kelompok yang paling terdampak ketika bencana terjadi. Anak-anak juga merupakan kelompok yang rentan mengalami trauma ketika bencana terjadi, sehingga penting untuk melibatkan anak-anak dalam pelatihan kebencanaan. Berikut ini adalah rencana pelaksanaan kegiatan yang dilakukan oleh Tim Abdimas UPNVJ: (1) Menonton film bersama anak-anak sekolah terkait dengan bencana alam dan upaya pencegahannya; (2) Mensosialisasikan potensi bencana alam dalam kegiatan anak-anak di luar jam sekolah dan langkah-langkah awal yang dapat diambil jika terjadi bencana alam; (3) Membuat standing banner tentang bencana alam yang dapat didisplay di tempat- tempat umum, seperti masjid, puskesmas dan sekolah.

\section{HASIL DAN PEMBAHASAN}

Kegiatan sosialisasi kesiapsiagaan bencana dilakukan dengan melibatkan siswa SD dan SMP di Kecamatan Cimanggu. Jumlah siswa SD dan SMP yang berpartisipasi pada kegiatan ini adalah sekitar 75 orang yang terdiri dari 3 kelas. Sebagai tahapan awal dari kegiatan adalah penyelenggaraan sosialisasi kesiapsiagaan bencana melalui penayangan beberapa video singkat yang telah dibuat oleh Badan Nasional Penanggulangan Bencana (BNPB). Salah satunya adalah video berjudul Tanggap, Tangkas dan Tangguh Menghadapi Bencana Gempa Bumi merupakan sebuah film edukasi singkat yang menjelaskan bagaimana Indonesia adalah negara yang rawan terhadap bencana gempa bumi, sehingga kita harus menyadari dan memiliki kesiapsiagaan terhadap resiko bencana yang dapat terjadi.

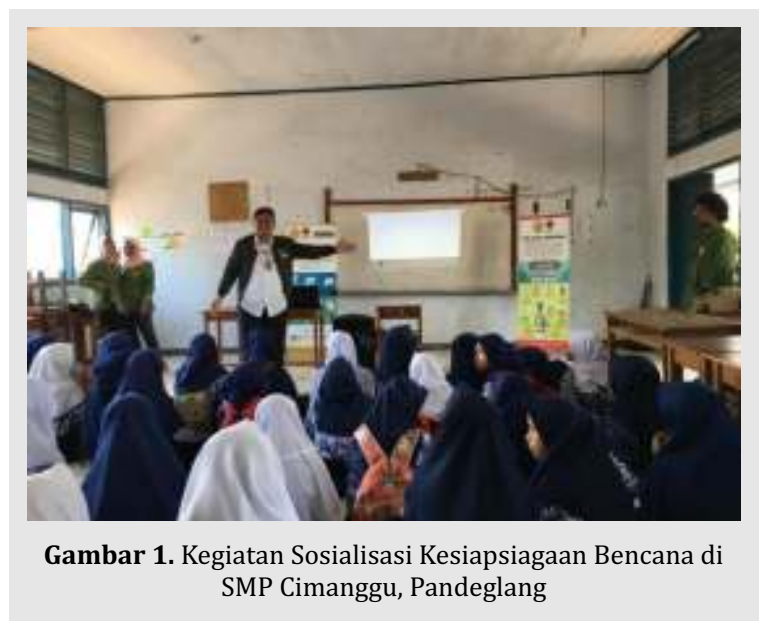

Setelah mendiskusikan tayangan video singkat yang telah disajikan, masing-masing siswa didorong untuk memberikan umpan balik melalui pertanyaan-pertanyaan yang dilontarkan dalam rangka mendapatkan tingkat pemahaman siswa terhadap tayangan edukasi bencana yang telah mereka saksikan. Hasilnya relatif signifikan, dimana hampir sebagian besar siswa memberikan feedback secara akurat. Berikut ini daftar pertanyaan yang disampaikan kepada siswa:

Table 1. Daftar Pertanyaan dan Umpan Balik Siswa

\begin{tabular}{|l|l|}
\hline Daftar Pertanyaan & Umpan Balik Siswa \\
\hline $\begin{array}{l}\text { 1. Langkah-langkah apa saja } \\
\text { yang dapat kita lakukan } \\
\text { pada saat terjadi bencana } \\
\text { gempa bumi? }\end{array}$ & $\begin{array}{l}\text { Sebagian siswa yang dipilih } \\
\text { secara acara berhasil } \\
\text { menjawab dengan tepat. }\end{array}$ \\
\hline $\begin{array}{l}\text { 2. Apa saja yang perlu kita isi } \\
\text { dalam Tas Siaga Bencana? }\end{array}$ & $\begin{array}{l}\text { Semua siswa yang dipilih } \\
\text { secara acak berhasil } \\
\text { menyebutkan satu persatu } \\
\text { barang-barang yang perlu } \\
\text { dipersiapkan dalam Tas } \\
\text { Siaga Bencana }\end{array}$ \\
\hline
\end{tabular}


Bagian kedua dari kegiatan ini adalah sosialisasi potensi bencana dan literasi kesiapsiagaan yang dilakukan di luar jam sekolah anak-anak. Kegiatan ini dilaksanakan di Taman Pintar Cimanggu Pandeglang yang sangat strategis karena berdekatan dengan sarana olah raga masyarakat desa serta tempat bermain anak-anak.

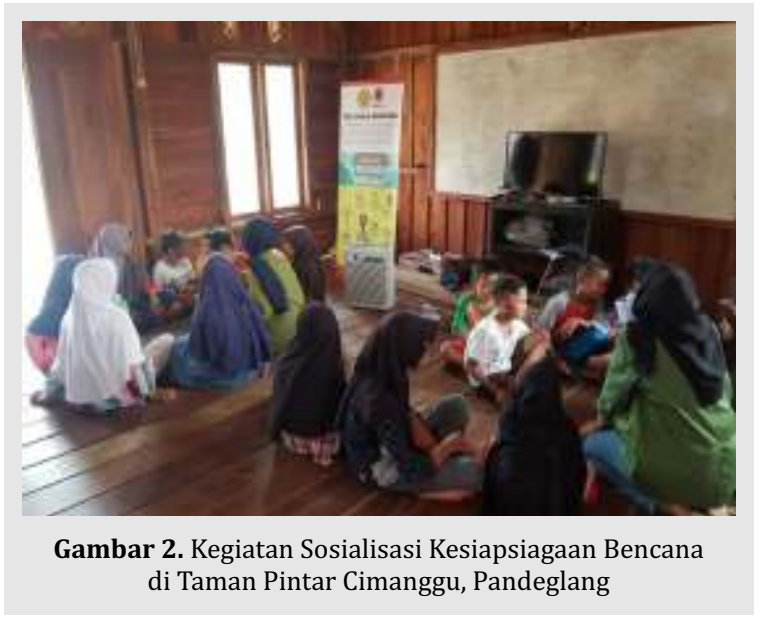

Tahapan ketiga adalah pemasangan alat-alat peraga dalam bentuk standing banner yang bertujuan untuk terus mengingatkan kepada masyarakat agar senantiasa siapsiaga apabila terjadi bencana sewaktu-waktu. Lokasi pemasangan di fokuskan kepada sekolah dan lokasi bermain anak-anak di Cimanggu, Pandeglang. Banner dibuat dalam dua narasi yang berbeda, pertama adalah langkah-langkah yang dapat dilakukan apabila terjadi peristiwa bencana, baik itu gempa bumi maupun tsunami. Banner kedua memberikan informasi tentang perlengkapan yang perlu dipersiapkan oleh kita semua dalam bentuk Tas Siaga Bencana.

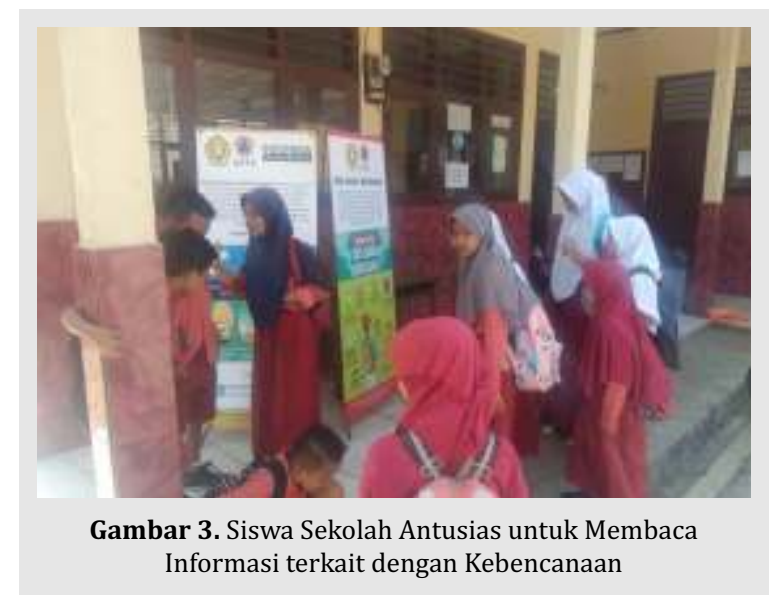

Tujuan diadakannya latihan kesiapsiagaan menghadapi bencana ini adalah untuk menjadikan pemangku kepentingan dapat merencanakan dan menjalankan latihan kesiapsiagaan bencana sesuai dengan potensi bencana di masing-masing daerah, khususnya dalam melakukan aktivasi sirine peringatan dini, latihan evakuasi mandiri di Sekolah/Madrasah, Rumah Sakit, gedung, serta pemukiman dan uji terap tempat pengungsian sementara/akhir (shelter) se-Indonesia. Menilai tindakan respon/reaksi masyarakat, baik individu, keluarga dan komunitas untuk melakukan evakuasi yang terencana. Selain itu juga untuk mengupayakan diadakannya latihan kesiapsiagaan bencana, tidak hanya yang dilakukan oleh pemerintah (pusat maupun daerah), namun juga oleh pihak-pihak lainnya, contohnya masyarakat, LSM, perguruan tinggi, sekolah, dan pihak swasta (hotel, pusat perbelanjaan, atau perusahaan lainnya).

\section{Jenis-Jenis Latihan Kesiapsiagaan Bencana}

Latihan adalah bagian yang sangat penting untuk meningkatkan kesiapsiagaan terhadap bencana. Terdapat 3 tahapan latihan, yaitu tahap pelatihan, tahap simulasi, dan tahap uji sistem. Alur pelaksanaan dari tahap-tahap tersebut adalah: (1) Pemahaman secara bertahap pada latihan kesiapsiagaan, dilakukan sejak tahap awal analisis kebutuhan, perencanaan, persiapan dan pelaksanaan, serta pengawasan dan evaluasi; (2) Berjenjang, artinya adalah latihan dilakukan dimulai pada tingkat yang paling sederhana, yaitu sosialisasi, hingga tingkat yang paling rumit, yaitu latihan terpadu atau gladi lapangan. Berbagai jenis latihan kesiapsiagaan tersebut ditujukan untuk meningkatkan kemampuan pemangku kepentingan, yaitu dari peningkatan pengetahuan, hingga sikap dan keterampilan saat melaksanakan fungsi dan tanggung jawab saat bencana terjadi; (3) Berkelanjutan, hal ini maksudnya adalah latihan kesiapsiagaan sesering mungkin dan secara konsisten.

Evakuasi mandiri merupakan salah satu jenis latihan kesiapsiagaan. Evakuasi mandiri merupakan kapabilitas dan aksi dari perorangan/masyarakat secara mandiri, cepat, 
tepat, dan terarah yang didasarkan pada langkahlangkah tertentu untuk menyelamatkan diri saat bencana terjadi. Latihan evakuasi mandiri dapat dilakukan oleh berbagai pihak, seperti sekolah, desa, perusahaan swasta, hotel, atau pihak-pihak lainnya. Latihan ini sendiri dilakukan sebagai respon terhadap sistem peringatan dini bencana.

\section{Tindakan Setelah Bencana}

Sejumlah hal yang perlu diketahui oleh masyarakat setelah bencana (seperti gempa bumi atau tsunami) terjadi adalah jauhi instalasi listrik bertegangan tinggi dan sampaikan kepada PLN jika menemukan adanya kerusakan instalasi listrik. Jauhi juga daerah yang mengalami kerusakan hingga dinyatakan aman, serta hindari bangunan yang mengalami kerusakan dan reruntuhan bangunan. Sebaiknya laporkan diri anda ke lembaga pemerintah/adat/keagamaan, serta usahakan untuk membuat penampungan sendiri apabila memungkinkan. Selain itu, anda dapat mengajak warga lain untuk melakukan hal-hal yang penting, seperti mengubur jenazah, mengumpulkan benda-benda yang masih dapat diselamatkan, atau melakukan doa bersama. Hal-hal ini dapat membantu kita untuk segera pulih dan memulai kehidupan secara normal. Jika diperlukan, anda dapat mencari bantuan dan bekerja sama, baik dengan warga lain, maupun dengan lembaga pemerintah/adat/keagamaan/ LSM. Beritahukan mengenai bencana ini kepada keluarga, anak, dan teman anda, sehingga mereka memiliki pengetahuan yang jelas dan tepat mengenai bencana tersebut. Beritahukan pula apa yang sebaiknya dilakukan apabila terjadi gempa atau muncul tanda-tanda terjadinya tsunami. Dengarkan radio atau televisi lokal untuk mendapatkan informasi terkini dan instruksi selanjutnya. Pemerintah setempat akan menyediakan jalan keluar yang sesuai dengan situasi terakhir. Periksa apabila ada luka-luka. Anda juga perlu memberi bantuan P3K untuk diri sendiri terlebih dahulu, barulah membantu orang lain hingga adanya bantuan dari pemerintah setempat. Bantulah tetangga yang memerlukan bantuan. Selain itu bantulah pihak-pihak yang lebih rentan seperti orang jompo, bayi, atau orang dengan disabilitas. Periksa apakah ada kerusakan di rumah. Gunakan lampu senter dan hindari penggunaan lilin, mengingat lilin dapat menimbulkan terjadinya kebakaran. Cek saluran listrik dan gas, mengingat apabila saluran ini rusak maka dapat menimbulkan terjadinya kebakaran. Cek bagian bangunan yang rawan runtuh dan usahakan untuk segera dirobohkan. Ambil sejumlah foto kerusakan rumah untuk keperluan klaim asuransi. Hubungi anggota keluarga lain untuk memberitahukan kondisi anda.

Saat Latihan Evakuasi di dalam Rumah/Sekolah: Hal yang dilakukan saat latihan evakuasi adalah petugas membunyikan peluit atau alat bunyi lain sebagai tanda dimulainya latihan. Peserta latih kemudian seolah-olah merasakan adanya peningkatan suhu ruangan yang signifikan dan suhu yang terasa sangat panas. Selain itu peserta latih juga seolah-olah mencium bau menyengat yang berasal dari gas beracun. Pelatihan pemadaman api juga dilakukan dengan alat pemadam api. Jika tidak ada alat pemadam api ringan (APAR), maka dapat diganti dengan soda kue. Untuk mengganti APAR, dapat juga digunakan karung goni atau kain yang telah dibasahi air. Hal ini dikarenakan karung goni atau kain yang basah dapat menutup pori-pori dan memecah udara masuk, sehingga api dapat padam. Selain itu juga dilakukan latihan untuk memutuskan aliran listrik apabila kebakaran disebabkan oleh korsleting listrik, serta latihan penyelamatan diri untuk mengantisipasi apabila api sudah tidak dapat dikendalikan.

Menurut hasil penelitian risiko bencana yang dilakukan oleh BNPB pada tahun 2015 (inarisk.bnpb.go.id), ditemukan sejumlah potensi dampak yang ditimbulkan oleh bencana, yaitu terdapat 5 jenis bencana yang berpotensi menimbulkan kerugian terbesar, yaitu cuaca ekstrem (puting beliung), kekeringan, banjir, gempa bumi, dan tanah longsor. Cuaca ekstrem (puting beliung) berpotensi berdampak terhadap 244 juta jiwa. Kekeringan berpotensi berdampak terhadap 228 juta jiwa serta berpotensi menimbulkan kerugian sebesar 192,7 triliun. Selain itu, bencana kekeringan juga berpotensi 
berdampak terhadap 63 juta hektar lahan. Gempa bumi berpotensi berdampak terhadap 86 juta jiwa serta berpotensi menimbulkan kerugian sebesar 648,8 triliun. Banjir berpotensi berdampak terhadap 100 juta jiwa serta berpotensi menimbulkan kerugian sebesar 376,8 triliun. Tanah longsor berpotensi berdampak terhadap 14 juta jiwa serta berpotensi menimbulkan kerugian sebesar 78,2 triliun. Selain itu, bencana tanah longsor juga berpotensi berdampak terhadap 41 juta hektar lahan. Bencana lain, yaitu kebakaran hutan dan lahan (karhutla), berpotensi berdampak terhadap 42 juta hektar lahan.

Oleh karena itu, BNPB sudah menyiapkan peta risiko bencana yang di dalamnya dijelaskan mengenai potensi jumlah jiwa yang terpapar bencana, serta potensi kerugian baik fisik maupun ekonomi. Hasil temuan BNPB menunjukkan bahwa semua orang di Indonesia rentan terpapar oleh bencana, sehingga semua pihak harus terlibat dalam penanganan bencana (everybody's business). Oleh sebab itu, perlu dilakukan berbagi peran dan tanggung jawab (shared responsibility) dalam peningkatan kesiapsiagaan di semua tingkatan, baik anak, remaja, dandewasa. Seperti yang telah dilakukan di Jepang, untuk menumbuhkan kesadaran kesiapsiagaan bencana.

\section{Manajemen Kesiapsiagaan Bencana}

Secara umum, kegiatan latihan kesiapsiagaan dibagi menjadi 5 (lima) tahapan utama, yakni tahap perencanaan, persiapan, pelaksanaan, serta monitoring dan evaluasi. Dalam bab ini, dijelaskan merencanakan (i) latihan Aktivasi Sirine Peringatan Dini, (ii) Latihan Evakuasi Mandiri di Sekolah/Madrasah, Rumah Sakit Siaga Bencana, Gedung, pemukiman, (iii) Uji Terap Tempat Pengungsian Sementara/Akhir (shelter) se-Indonesia, Tahapan latihan kesiapsiagaan ini diperlihatkan pada gambar berikut:

\section{Tahap Perencanaan}

Pembentukan Tim Perencana dilakukan melalui sejumlah tahap, yaitu: (1) Dilakukan pembentukan organisasi latihan kesiapsiagaan agar penerapan evakuasi dapat dilaksanakan dengan baik dan sukses. Jumlah anggota dari organisasi tersebut tergantung dari tingkat kesulitan dari latihan yang akan dilakukan; (2) Anggota organisasi latihan kesiapsiagaan memiliki tanggung jawab terhadap perencanaan, pelaksanaan, serta akhir dari latihan. Tugas dari tim perencana ini adalah sebagai pengarah, penanggung jawab, serta pengendali ketika latihan dilaksanakan, (3) Tugas dari masing-masing anggota adalah sebagai pengarah (bertanggung jawab memberi masukan yang bersifat kebijakan untuk penyelenggaraan latihan kesiapsiagaan, dan dapat memberikan masukan yang bersifat teknis dan operasional, mengadakan koordinasi, serta menunjuk penanggung jawab organisasi latihan kesiapsiagaan) atau sebagai penanggung jawab, (membantu pengarah melalui pemberian masukan-masukan, baik yang bersifat teknis, kebijakan, maupun operasional pada saat pelaksanaan latihan kesiapsiagaan); (4) Anggota yang berada pada bagian operasional latihan melakukan sejumlah tugasnya saat latihan. Tugas tersebut antara lain adalah memberikan peringatan dini, melakukan pertolongan pertama, serta membantu pelaksanaan proses evakuasi dan penyelamatan, serta mengelola logistik dan menjaga keamanan. Tugas-tugas tersebut diuji saat latihan dilakukan; (5) Anggota yang berada pada bagian evaluasi bertugas untuk mengevaluasi pelaksanaan latihan kesiapsiagaan, sehingga pelaksaan latihan kesiapsiagaan selanjutnya dapat dilaksanakan dengan lebih baik.

Secara lebih rinci, tugas dari tim perencana ini adalah: (1) Merumuskan risiko atau ancaman dari bencana yang akan disimulasikan dalam latihan kesiapsiagaan; (2) Memilih skenario bencana yang akan disimulasikan dalam latihan kesiapsiagaan; (3) Menentukan strategi dari pelaksanaan latihan kesiapsiagaan; (4) Menyusun kerangka dari latihan simulasi kesiapsiagaan (tipe dari simulasi yang akan dilakukan, maksud dari simulasi, tujuan dari simulasi, serta ruang lingkup latihan kesiapsiagaan).

\section{Menyusun Rencana Latihan Kesiapsiagaan}

Penyusunan rencana latihan kesiapsiagaan 
(berupa aktivasi sirine maupun evakuasi mandiri) akan mengikutsertakan penduduk di lingkungan tersebut, baik yang ada di permukiman, kantor, sekolah, maupun di area publik. Isi dari rencana latihan kesiapsiagaan adalah: (1) Tujuan, sasaran, dan waktu pelaksanaan dari latihan kesiapsiagaan; (2) Penyusunan skenario latihan kesiapsiagaan. Skenario berperan sebagai panduan jalan cerita kejadian terjadinya bencana yang digunakan saat pelaksanaan pelatihan. Skenario disusun serealistis mungkin sesuai dengan kejadian bencana dengan probabilitas yang paling tinggi terjadi di desa tersebut; (3) Skenario yang sudah disusun sebaiknya dipahami oleh setiap pihak yang terlibat, baik pelaksana latihan kesiapsiagaan, maupun peserta yang mengikuti latihan tersebut; (4) Melakukan evaluasi dan pengkajian kembali SOP/Protap yang sudah ada; (5) Melakukan pemeriksaan terhadap tempat yang dapat dijadikan sebagai pusat evakuasi, tempat pengungsian, atau tempat perlindungan sementara. Tempat tersebut dapat menggunakan lokasi-lokasi tertentu, seperti area terbuka, sekolah, kantor, sekolah, tempat ibadah, atau gedung lainnya. Tempat tersebut dipilih berdasarkan kondisi lingkungan, keterjangkauan, serta keamanannya.; (6) Penentuan lokasi pengungsian sebaiknya dilakukan dengan mempertimbangkan ketersediaan logistik (seperti makanan atau minuman, pakaian, obat-obatan dan peralatan medis, perlengkapan untuk tidur, peralatan kebersihan, dan bahan bakar), maupun ketersediaan fasilitas umum; (7) Pemilihan ancaman yang akan diskenariokan saat latihan kesiapsiagaan sebaiknya disesuaikan dengan ancaman bencana yang paling mungkin terjadi di daerah tersebut. Informasi mengenai hal tersebut dapat diakses di situs inarisk.bnbp.go.id.

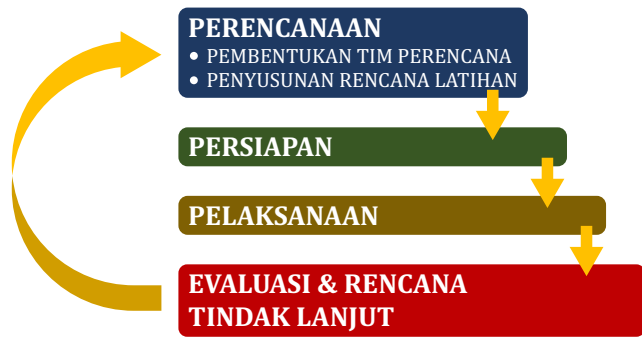

Gambar 4. Bagan Manajemen Kesiapsiagaan Bencana

\section{SIMPULAN DAN SARAN}

Letak geografis Indonesia yang berada di Cincin Api Pasifik (Pacific Ring of Fire) menjadikan Indonesia sebagai salah satu negara dengan potensi bencana alam yang cukup signifikan. Kejadian terbaru adalah Tsunami Selat Sunda yang menerjang Pandeglang dan sebagian wilayah di provinsi Lampung pada 22 Desember 2018. Pandeglang sendiri dikategorikan sebagai salah satu wilayah rentan bencana alam, mengingat letak geografisnya yang memiliki garis pantai sepanjang $307 \mathrm{~km}$ dan berdekatan dengan Gunung Krakatau. Salah satu kawasan di Pandeglang yang dianggap rentan terhadap bencana tsunami dan aktivitas Anak Gunung Krakatau adalah Kecamatan Sumur dan Cimanggu. Oleh karena itu, diperlukan perhatian khusus terhadap masyarakat yang bermukim di kedua wilayah tersebut dalam rangka kesiapsiagaan dan penanggulangan bencana.

\section{Kesimpulan}

Pelatihan kebencanaan memiliki peran penting dalam meningkatkan kesiapsiagaan terhadap bencana, serta meningkatkan kemampuan untuk menyelamatkan diri. Kegiatan sebelum bencana yang mengedepankan mitigasi bencana /kesiapaan bencana (disaster mitigation/disaster preparedness) termasuk pelatihan kebencanaan, masih relatif terbatas. Untuk itu, perguruan tinggi dapat menjalankan perannya sebagai institusi pendidikan yang hadir dalam memberikan literasi dan pemberdayaan masyarakat agar senantiasa siap dan siaga dalam penanggulangan bencana alam di wilayah tempat tinggal mereka. Oleh karena itu, tim Abdimas UPNVJ menyelenggarakan peningkatan kesadaran masyarakat (disaster awareness) yang melibatkan siswa sekolah di Kecamatan Cimanggu, Pandeglang. Sejumlah kegiatan yang dilakukan adalah: (1) Menonton film bersama anak-anak sekolah terkait dengan bencana alam dan upaya pencegahannya; (2) Mensosialisasikan potensi bencana alam dalam kegiatan anak-anak di luar jam sekolah dan langkah-langkah awal yang dapat diambil jika terjadi bencana alam; (3) Membuat standing banner tentang bencana alam yang dapat di-display di tempat- tempat umum, 
seperti masjid, puskesmas dan sekolah. Adanya kegiatan ini diharapkan dapat membantu untuk membangun anak-anak tangguh bencana di wilayah Cimanggu.

\section{Saran}

Usul dan saran untuk program untuk kedepannya adalah kegiatan ini dapat terus dikembangkan dan melibatkan lebih banyak lagi siswa sekolah melalui berbagai format kegiatan menarik dan edukatif. Selain itu, memang sebaiknya pengetahuan tentang kebencanaan sudah harus diperkenalkan sejak usia sekolah dasar. Salah satunya dapat dilakukan dengan menyesuaikan kurikulum atau kegiatan-kegiatan ekstrakurikuler yang dapat mendukung program kesiapsiagaan dan pengurangan resiko bencana khususnya di wilayah Cimanggu atau kawasan rawan bencana lainnya. Kedepannya, kegiatan seperti ini juga dapat melibatkan unsur masyarakat lainnya selain anak-anak sekolah, seperti pegawai pemerintahan, warga setempat, maupun kelompok rentan (lansia, penyandang disabilitas, orang berkebutuhan khusus, dan tunawisma).

\section{DAFTAR PUSTAKA}

Aji, M. R. (2018). Saat Anak-anak Korban Tsunami Banten Jalani Trauma Healing. Diambil dari https://nasional.tempo.co/read/1160323/saat-anak-anak-korban-tsunami-banten-jalani-trauma -healing

Badan Nasional Penanggulangan Bencana. (2016). Risiko Bencana Indonesia. Jakarta, Indonesia: Badan Nasional Penanggulangan Bencana.

Hakim, R. M. (2018). Update Tsunami Selat Sunda: 426 Orang Meninggal Dunia, 7.202 Luka-luka, dan 23 Orang Hilang. Diambil dari https:// nasional.kompas.com/ read/ 2018/12/28/15102481/updatetsunami-selat-sunda-426-orang-meninggal-dunia-7202-luka-luka-dan-23

Prihatmaji, Y. P., Widodo, E., \& Nugroho, I. (2013). Penyuluhan Peningkatan Kesadaran Masyarakat Terhadap Tanggap Bencana (Khususnya Longsor). Jurnal Inovasi dan Kewirausahaan, 2(2),119-123.

Soleman, M. K., Nurcahyani, F., \& Munajati, S. L. (2012). Pemetaan Multirawan Bencana di Provinsi Banten (Multihazard Mapping of Banten Province). Globe, 14(1), 46-59.

WWF-Indonesia. (2019). Delapan desa penyangga dan WWF-Indonesia gelar lokakarya ketahanan terhadap bencana alam di Kabupaten Pandeglang. Diambil dari https://www.wwf.id/upload/2019/07/SIARAN_PERS_Lokakarya_Ketahanan_Terhadap_Bencana_ Alam_di_Kabupaten_Pandeglang_.pdf 